\title{
VOTING RIGHTS OF INTERNALLY DISPLACED PERSONS IN NIGERIA'S 2015 GENERAL ELECTIONS
}

\section{Emeka C. Iloh, Michael E. Nwokedi, Cornelius C. Mba and Kingsley O. Ilo}

\author{
Emeka C. Iloh is Research Fellow \\ African Heritage Institution, Enugu, Nigeria \\ Michael E. Nwokedi is a lecturer in the \\ Social Science Unit, School of General Studies, \\ University of Nigeria, Nsukka \\ Cornelius C. Mba is a lecturer in the \\ Department of Public Administration \\ Madonna University, Okija, Nigeria \\ Kingsley O. Ilo is a lecturer in the \\ Social Science Unit, School of General Studies, \\ University of Nigeria, Nsukka
}

\begin{abstract}
The study examines the extent to which Nigeria's electoral body complied with existing legal frameworks on Internally Displaced Persons' (IDP) voting during the 2015 general elections. The existing legal frameworks in question consist of two international frameworks which Nigeria adopted, and two domestic frameworks. The United Nations Guiding Principles on Internally Displaced Persons, and the African Union Convention for the Protection and Assistance of Internally Displaced Persons in Africa, otherwise known as the Kampala Convention, are the two international frameworks. The domestic legal frameworks include the 1999 Constitution (as amended) and the Electoral Act 2010 (as amended). Data for the study was generated through interviews with officials of the electoral body of Nigeria. This was complemented by documentary evidence based on secondary sources, including Nigeria's election reports, the Electoral Act 2010, the 1999
\end{abstract}


Constitution of the Federal Republic of Nigeria, and other relevant materials. Data were analysed using content analysis rooted in logical deduction. The result of the data analysis shows that the handling of the voting rights of IDPs in Nigeria's 2015 general elections by the electoral body contravened all the existing legal frameworks that guide IDP voting. The study therefore recommends that a system of electronic voting should be introduced in Nigeria to enable all eligible Nigerians, including IDPs, to vote in whichever part of the country they are resident at the time of the election.

\section{INTRODUCTION}

Since the introduction of the electoral principle in 1922, Nigeria's electoral laws have been deficient in ensuring the electoral rights of all adult Nigerians who have attained the voting age of 18 years. The Clifford Constitution of 1922 introduced the elective principle but restricted elections to Lagos and Calabar only. This restriction meant that only four Nigerians - three from Lagos and one from Calabar - were elected onto the legislative council (Okereka 2015). Under this constitution, franchise was further restricted to male Nigerians with a minimum gross income of US\$100 annually (Aghalino 2006). A further condition was the residential qualification of one year in either Lagos or Calabar (African Heritage 2012). The implication of the above is that franchise was granted only to Africans who must have been residents of either Lagos or Calabar for at least one year, and who had a minimum gross income of US $\$ 100$ annually. Subsequent constitutional amendments broadened the electoral space, but it was not until 1979 that Nigeria's Constitution granted the right to vote and to be voted for to all Nigerians who had attained the age of 18 , irrespective of economic status and gender. Thus, the first time women in northern Nigeria were allowed to participate in elections was in 1979 (Azinge 1994).

The quality of elections is measured not only by the extent to which the franchise is guaranteed and elections are impartially administered for the majority of voters, but also by accommodations to enfranchise voters who are marginalised in the polity. The 1979 Constitution that introduced the universal adult suffrage in Nigeria, and subsequent electoral laws, failed to accommodate all eligible voters. Voters with special needs are often neglected when these electoral laws are designed. In other words, electoral laws in Nigeria often disregard the need for special provisions to facilitate voting by citizens who are elderly, disabled, or live in remote locations. More importantly, these laws have often failed to accommodate citizens who have been displaced from their homes or their places of residence due to conflicts, natural disasters, and other sources of dislocation. Thus, as the 2015 general elections in Nigeria drew closer, the upsurge in the 
number of displaced persons and the fact that there were no legal provisions to guarantee their electoral rights became an issue. Enfranchising these displaced voters was one of the biggest challenges that confronted Nigeria in the run-up to the 2015 general elections.

Francis Deng was the United Nations' first Special Rapporteur on the Human Rights of Internally Displaced Persons. In his introductory note to the Guiding Principles on Internal Displacement he defined internally displaced persons as 'persons forcibly uprooted from their homes by violent conflicts, gross violations of human rights and other traumatic events, but who remain within the borders of their own countries' (UNHCR 1998, p. 1). In the same vein, the Internal Displacement Monitoring Center (IDMC), a leading source of information and analysis on internal displacement and part of the Norwegian Refugee Council (NRC), defined internal displacement as a situation in which persons or groups of persons have been forced or obliged to flee or to leave their homes or places of habitual residence, in particular as a result of or in order to avoid the effects of armed conflict, situations of generalised violence, violations of human rights or natural or human-made disasters, and who have not crossed an internationally recognised state border (IDMC 2015b; UNHCR 1998). This implies that the causes of internal displacement are multifaceted, complex and often over-lapping. In Nigeria specifically, internal displacement has been caused by intercommunal clashes fuelled by ethnic and religious tensions; flooding; urban renewal/statesponsored evictions by both federal and state governments; and fear of electoral violence. However, the highest singular cause of displacement in Nigeria after the floods of 2012 is insurgency orchestrated by the Islamist Boko Haram, mainly in the north-eastern states of Adamawa, Borno and Yobe. The activities of this group have not only left thousands of people dead, but have also left even more homeless as many have been displaced from their residences. IDMC (2016) estimated that there were about 2152000 IDPs in Nigeria as of 31 December 2015. This figure is based on an assessment conducted from November to December 2015 by the International Organization for Migration (IOM) Displacement Tracking Matrix (DTM) team in 207 Local Government Areas (LGAs) covering 13 states in northern Nigeria. According to the same IDMC report, of these 2152000 IDPs in Nigeria, $12.6 \%$ (271 152 IDPs) were displaced due to communal clashes, 2.4\% (51 648 IDPs) were displaced by natural disasters, and 85\% (1 829200 IDPs) were displaced as a result of insurgency attacks by the Islamist Boko Haram.

These numbers are significant in any electoral contest, since they could make the difference between either winning or losing an election. More importantly, displaced persons have equal rights to those of every other citizen to participate in the electoral activities of their countries. The need to protect these rights and the 
fact that there were no legal instruments that specifically provided for IDP voting in Nigeria compelled the Independent National Electoral Commission (INEC), Nigeria's elections management body, to resort to international protocols that guide IDP voting and some sections of domestic law (which granted franchise to all eligible citizens) to administer IDP voting in the country. This study, therefore, assesses the extent to which INEC complied with these existing international and domestic requirements in the conduct of the 2015 general elections.

\section{PROBLEM STATEMENT}

Before the 2015 general elections, management of the humanitarian crisis caused by the surge in the number of IDPs was a serious issue for the government and its agencies. The provision of shelter, healthcare, and rehabilitation was a huge challenge; so too was preventing and addressing the causes of displacement in the first place. The immediate priorities of IDPs then were food, water, health, shelter, protection, security, and sanitation. To address these challenges, the government provided 17 temporary IDP camps in Adamawa state and another ten in Borno state by December 2014 (Ibeanu 2015). These camps were located in churches, mosques, schools and other public places. Relief materials and drugs were sent frequently to these camps by government agencies such as the National Emergency Management Agency (NEMA), State Emergency Management Agencies (SEMAs) and other humanitarian agencies. However, as the 2015 general elections drew closer, the voting rights of IDPs were also elevated to being equally important, and formed part of the topical issues that engaged stakeholders. There were concerns that a significant number of registered voters might be disenfranchised owing to the fact that they had been displaced from their homes/wards where they registered to vote. Before the 2015 general elections, IDP voting was alien to Nigeria's political and electoral lexicon because the country had not experienced prolonged displacement of this magnitude in the past. This was captured by Ibeanu $(2015$, p. 20$)$ when he noted that it was the proposed gubernatorial byelection in Adamawa State that 'brought the full magnitude of the IDP challenge in the electoral process to the attention of the Commission for the first time'. According to Ibeanu, the large number of IDPs in Adamawa State convinced INEC of the need for urgent response to the situation, otherwise a significant percentage of registered voters would be disenfranchised.

The attention of the National Assembly was also drawn to the debate on whether IDPs would vote in the 2015 general elections or had been disenfranchised as a result of having been displaced from where they had registered to vote. The Senate in particular considered an amendment to the Electoral Act 2010 (as amended) to make provision for IDPs to vote in their respective camps nationwide 
through a proposed insertion of Section 42 (2) into the Electoral Act. The insertion of this sub-section into the Electoral Act would have given a legal backing to IDPs voting in Nigeria. However, the bill was later stalled at its second reading in December 2014 as the Senate was of the view that a resolution employing INEC to use all administrative mechanisms within the Electoral Act to ensure that IDPs of adult age exercise their franchise in time of general elections would be more effective (PLAC 2015). Hence, on 16 December 2014, Senate directed its Committee on INEC to liaise with INEC to establish special polling units for IDP victims of insurgency in the north-east (CLEEN Foundation 2014). Consequently, INEC established a task force on how to get the IDPs to vote during the elections. One important recommendation of the task force was that special voting centres should be set up for the IDPs in the north-east. Thus, weeks before the elections, Attahiru Jega, then INEC chairman, gave the assurance that these special centres would not only be set up, but also that they would be used for the distribution of Permanent Voters Cards (PVCs) to the IDPs. To allay the fears of the opposition that these camps (with the voting centres) would be hijacked by the parties in power in those states, the Chairman of INEC confirmed that these centres would not be set up inside the IDP camps (African News 2015).

As arrangements were being put in place to ensure that the IDPs in the north-eastern part of the country were not disenfranchised, INEC announced that registered voters fleeing their present abode to return to their states of origin for fear of outbreak of violence during and after the general elections would not be allowed to vote in their home states (Nweje 2015). This seems to be the problem, especially considering that no other reason was adduced by INEC for taking such a decision except that of convenience, and the fact that IDPs in the three states of Adamawa, Borno and Yobe were more accessible because most of them lived in camps. According to the definition of internally displaced persons, those people who fled from their abode qualify as IDPs because they have been forced or obliged to flee or to leave their homes or places of habitual residence. This is particularly as a result of, or in order to avoid the effects of armed conflict; situations of generalised violence; violations of human rights; natural or humanmade disasters; and who have not crossed an internationally recognised state border.

Why then was arrangement made for some IDPs to exercise their franchise while others were denied such rights? According to INEC, those people who registered and obtained their Permanent Voters Cards (PVCs) in one part of the country but fled to another could only return to the place of registration if they wished to vote. Those in question feared that there might be a repeat of the painful experience of the post-election violence of 2011, where dozens of people were killed, many more injured, and several houses and vehicles were either destroyed or burnt. This fear was exacerbated by the threats issued during the 
campaigns, especially in the north where hate speech was the order of the day. The presidential candidate of the opposition All Progressives Congress (APC) openly threatened violence if the elections were rigged. In order to escape the violence that was palpable, especially in the northern part, most southerners residing in the north resolved to go back to their home states for safety and to vote there. This was despite the fact that they had registered to vote in the north.

The question that arises from the foregoing is: based on extant laws, were the voting rights of the IDPs in Nigeria adequately protected during the 2015 general elections in the country? Against this background the study examines the extent to which INEC complied with the relevant legal frameworks that guide IDP voting in the conduct of the 2015 general elections in Nigeria. The findings show that to a large extent, INEC did not comply with the legal frameworks that guide IDP voting in the administration of the 2015 general elections in Nigeria.

\section{METHODOLOGY}

The study relied on both survey and documentary methods. First, to generate data from the survey, unstructured interviews were used. To augment these interviews, Focus Group Discussions (FGD) were also used. Here, the opinions of experts knowledgeable about IDP voting were sampled. We restricted our respondents to the most senior INEC officials that worked in the three IDP voting states of Adamawa, Borno and Yobe. There were two of these officials in each of these states: a chief administrative officer in charge of logistics (deployment of ad hoc staff and voting materials) and another in charge of operations and elections monitoring. Purposive sampling technique was used to select only the chief administrative officers in charge of operations and elections monitoring. We adopted this technique because we intended to concentrate on those who had been in the field as election monitors and were best suited to assist with relevant information. As a result, they had first-hand information on the administration of IDP voting in the three IDP voting states. The essence of the entire interview exercise was to corroborate or cross-match the documentary evidence in order to arrive at the facts of our study. Many of the issues raised in the study, especially as regards to reasons for not extending the franchise to IDPs in the southern part of the country, were based on the FGD and interviews. The FGD and interviews also afforded the authors insight into options available for INEC in subsequent elections regarding IDP voting. In particular, those interviewed suggested that electronic voting would go a long way to solving the problems encountered in the 2015 IDP voting exercise. Second, we also relied on secondary data generated by the documentary method. These included data collected from external sources such as official documents which include INEC's 2015 General Elections Report, other institutional reports, text books, journals, conference papers, magazines, 
the internet, and studies from civil society organisations (CSOs) and other stakeholders in the election.

In order to analyse the data, content analysis rooted in logical deduction was used. This means sifting through and retrieving meaningful information from the mass of data we gathered from the interviews, books, documents, journal articles, conference papers etc., then systematically reducing them to a logical, meaningful and coherent interpretation, and on that basis drawing our inferences and conclusions.

\section{VOTING RIGHTS OF IDPS IN THE 2015 GENERAL ELECTIONS AND EXISTING LEGAL FRAMEWORKS FOR IDP VOTING}

This section examines the extent to which INEC complied with the relevant legal frameworks guiding IDP voting with a view to determining whether it infringed on the voting rights of IDPs in Nigeria. There are two such international frameworks: the United Nations Guiding Principles on Internally Displaced Persons, 1998 and the African Union Convention for the Protection and Assistance of Internally Displaced Persons in Africa, 2007 otherwise known as the Kampala Convention. There are also two such domestic legal frameworks: the 1999 Constitution of the Federal Republic of Nigeria (as amended) and the Electoral Act 2010 of the Federal Republic of Nigeria (as amended). As regards the voting rights of the IDPs, they include, but are not limited to: the right to vote and to be voted for (Nigerian 1999 Constitution 77[2], 117[2]; Nigerian Electoral Act 2010 12[1]; Kampala Convention 9[2] [1]); right to freedom from discrimination in the political process (Guiding Principles 1[1], 22[1d]); right to voluntary return to former places of habitual residence (Guiding Principles 15[d]; Kampala Convention 11[2]); and right to replacement of documents lost during displacement (Guiding Principles 20[2]; Kampala Convention 13[3]).

\section{IDP Voting Rights, the United Nations Guiding Principles, and the Kampala Convention}

The Guiding Principles is one of the two most comprehensive frameworks that have shaped current international standards on IDPs. They were developed as a response to the growing global challenge of internal displacement. Ibeanu (2015) has articulated the different stages of global population displacement from 1648 to 2015. In response to the changing character of the global problem of population displacement, in 1992 the then United Nations Secretary General, Boutros Boutros-Ghali appointed Francis Deng as the Representative of the UN Secretary General on Internally Displaced Persons, with a mandate to compile international standards comprising the normative framework for addressing internal displacement. The result was the Guiding Principles on Internal Displacement, 
which was presented to the UN Commission on Human Rights in 1998 (Brookings Institution 2008). These principles reflect, and are consistent, with international human rights law and international humanitarian law. They restate in greater detail guarantees relevant to the displaced that are implicit in the more abstract prescription of these bodies of law.

Although the Guiding Principles have yet to metamorphose into a global convention, they have over the years acquired political, if not legal force. Since their promulgation, they have been accorded almost universal recognition as the normative departure point for dealing with displacement. The Brookings Institution $(2008$, p. 3$)$ has noted that the heads of states and governments assembled in September 2005 in New York for the World Summit recognised the Guiding Principles as an 'important international framework for the protection of internally displaced persons', an endorsement reiterated by the General Assembly on several occasions. In addition, the African Union, the Organization of American States, and the Council of Europe have called upon their member states to use the Guiding Principles and incorporate them into their domestic laws and policies (Brookings Institution 2008). The Guiding Principles formed part of the legal frameworks considered by INEC in the administration of IDP voting during the 2015 general elections in Nigeria (Ibeanu 2015; INEC 2015b). Table 1 below shows the provisions of the Guiding Principles that provide for the voting rights of IDPs.

\section{Table 1}

\section{Provisions of the Guiding Principles on the Voting Rights of IDPs}

\begin{tabular}{|l|l|}
\hline Principle & Provisions \\
\hline $1(1)$ & $\begin{array}{l}\text { IDPs shall enjoy in full equality, the same rights and freedoms under interna- } \\
\text { tional and domestic law as do other persons in their country. They shall not } \\
\text { be discriminated against in the enjoyment of any rights and freedoms on the } \\
\text { ground that they are internally displaced. }\end{array}$ \\
\hline 15(d) & $\begin{array}{l}\text { Internally displaced persons have the right to be protected against forcible } \\
\text { return to or resettlement in any place where their life, safety, liberty and or } \\
\text { health would be at risk. }\end{array}$ \\
\hline 20(2) & $\begin{array}{l}\text { The authorities concerned shall issue IDPs all documents necessary for the en- } \\
\text { joyment and exercise of their legal rights, such as passports, personal identifi- } \\
\text { cation documents, birth certificates and marriage certificates. In particular, the } \\
\text { authorities shall facilitate the issuance of new documents or the replacement of } \\
\text { documents lost in the course of displacement, without imposing unreasonable } \\
\text { conditions, such as requiring the return to one's area of habitual residence in } \\
\text { order to obtain these or other required documents. }\end{array}$ \\
\hline 22(1)(d) & $\begin{array}{l}\text { IDPs, whether or not they are living in camps, shall not be discriminated } \\
\text { against as a result of their displacement in the enjoyment of. . the right to vote } \\
\text { and to participate in governmental and public affairs, including the right to } \\
\text { have access to the means necessary to exercise this right. }\end{array}$ \\
\hline
\end{tabular}




\begin{tabular}{|l|l|}
\hline 29(1) & $\begin{array}{l}\text { Internally displaced persons who have returned to their homes or places of } \\
\text { habitual residence or who have resettled in another part of the country shall... } \\
\text { have the right to participate fully and equally in public affairs at all levels and } \\
\text { have equal access to public services. }\end{array}$
\end{tabular}

Source: UNHCR (1998). Guiding Principles on Internal Displacement

Mooney and Jarrah (2004) have argued that it was important to include in the Guiding Principles the provisions listed in Table 1 for protecting the voting rights of IDPs, because it had been determined that these rights were routinely at risk of being violated in situations of internal displacement. It is in this light, therefore, that we analyse INEC's handling of the voting rights of IDPs in the 2015 general elections vis-a-vis the provisions of the Guiding Principles.

First, Principle 1(1) of the Guiding Principles, which could be termed the principle of non-discrimination, was not adhered to in the conduct of the 2015 general elections. There was an official discrimination against IDPs from other parts of the country as only IDPs in Adamawa, Borno and Yobe states were accommodated in the special arrangements INEC made to ensure that IDPs were not disenfranchised during the 2015 general elections. Second, Principle 15(d) provides that IDPs cannot be forcibly sent back to the troubled areas where their life, safety, liberty and/or health would be at risk. In this regard, there was clear violation of the Guiding Principles in INEC's insistence that other IDPs who were no longer within the three states, or those displaced in other states, and most importantly, those preventively escaping from anticipated electoral violence, must return to those areas where they registered if they wished to vote. This affected mainly southerners who fled from the north either as a result of insurgency or in anticipation that violence might break out during the elections, as was the case in previous elections. They were technically denied the right to vote because they could not risk their lives by returning to the same area from which they escaped, only in order to vote. Third, Principle 22(1) (d) of the Guiding Principles provides that IDPs, whether or not they are living in camps, shall not be discriminated against. But one of the reasons advanced by INEC for concentrating the arrangements in the north-east alone was that of convenience and accessibility: IDPs in the affected states were mostly in camps and could be easily accessed. The implication of such an arrangement is that IDPs in those three states who were neither living in camps nor close to voting centres (which had been established where there was a large concentration of IDPs) were also disenfranchised. The National Emergency Management Authority (NEMA) (2015) has noted that only $12 \%$ of the IDP population in Adamawa State and 18\% of IDPs in Borno State lived in camps or camp-like settings by the end of 2014. This means that a larger 
percentage of IDPs who were scattered among host communities and who did not live close to voting centres were disenfranchised, in violation of the Guiding Principles. Tables 2 and 3 show IDPs living in different camps and their population in Adamawa and Borno States.

Table 2

IDPs in Camps in Adamawa State (December 2014)

\begin{tabular}{|c|l|l|r|}
\hline S/N & Name of Camp & Location & Population \\
\hline $\mathbf{1}$ & Girei & Girei LGA & 3000 \\
\hline $\mathbf{2}$ & NYSC Camp & Damare Area, Girei LGA & 5382 \\
\hline $\mathbf{3}$ & Malkoli Camp & Malkoli Ward, Yola South LGA & 892 \\
\hline $\mathbf{4}$ & St. Theresa Catholic Church & Luggere Ward, Yola North LGA & 5034 \\
\hline $\mathbf{5}$ & State Polytechnic & Karewa Ward, Yola North LGA & 468 \\
\hline $\mathbf{6}$ & Cocin Church & Kofare Area, Yola North LGA & 97 \\
\hline $\mathbf{7}$ & Daware & Fufore LGA & 1540 \\
\hline $\mathbf{8}$ & Malkoli Village & Malkoli Ward, Yola South LGA & 319 \\
\hline $\mathbf{9}$ & Bekaji A\&B & Karewa Ward, Yola North LGA & 387 \\
\hline $\mathbf{1 0}$ & Karewa & Karewa Ward, Yola North LGA & 1564 \\
\hline $\mathbf{1 1}$ & Nyako Housing Estate & Wuro Jebbe Area, Yola South LGA & 1232 \\
\hline $\mathbf{1 2}$ & Girei 1 (Transit Camp) & Girei LGA & 1074 \\
\hline $\mathbf{1 3}$ & Low Level Water Board & Jimeta, Yola North LGA & 600 \\
\hline $\mathbf{1 4}$ & Yola Central Mosque & Yola North LGA & 4253 \\
\hline $\mathbf{1 5}$ & Izala Mosque Jam Block & Jimeta, Yola Noth LGA & 1230 \\
\hline $\mathbf{1 6}$ & GSS Numan & Numan LGA & 1432 \\
\hline $\mathbf{1 7}$ & Ganye & Ganye LGA & $\mathbf{2 8} 819$ \\
\hline & Total & & \\
\hline
\end{tabular}

Source: Ibeanu (2015, p. 32)

Table 3

IDPs in Camps in Borno State (December 2014)

\begin{tabular}{|c|l|l|c|}
\hline S/N & Name of Camp & Location & Population \\
\hline $\mathbf{1}$ & Yerwa GGSS & Bama and Damboa & 8567 \\
\hline $\mathbf{2}$ & NYSC Camp & Bama and Damboa & 10234 \\
\hline $\mathbf{3}$ & $\begin{array}{l}\text { Government College Mai- } \\
\text { duguri }\end{array}$ & Gwoza & 17689 \\
\hline
\end{tabular}




\begin{tabular}{|c|l|l|c|}
\hline $\mathbf{4}$ & Arabic Teachers College & Askira/ Uba and Gwoza & 8176 \\
\hline $\mathbf{5}$ & $\begin{array}{l}\text { Government Girls } \\
\text { College, Maiduguri }\end{array}$ & Bama & 6532 \\
\hline $\mathbf{6}$ & $\begin{array}{l}\text { Women's Teachers } \\
\text { College, Maiduguri }\end{array}$ & Bama & 4289 \\
\hline $\mathbf{7}$ & $\begin{array}{l}\text { Sanda Kyarimi Day } \\
\text { Secondary School }\end{array}$ & Ngala and Dikwa & 10451 \\
\hline $\mathbf{8}$ & CBDA Headquarters & Marte, Ngala and Dikwa & 10975 \\
\hline $\mathbf{9}$ & Teachers Village & Ngala, Mobbar and Gubio & 10342 \\
\hline $\mathbf{1 0}$ & E.Y.N. Church & Gwoza & 10349 \\
\hline & Total & & $\mathbf{9 7 6 0 4}$ \\
\hline
\end{tabular}

Source: Ibeanu (2015, pp. 32-33)

The two tables above indicate that there were 126423 IDPs in 27 camps in Adamawa and Borno States (there were no camps in Yobe State at the time). This figure, though electorally significant, is small when juxtaposed with the over one million registered voters in the affected areas of the three states. In other words, fewer than 127000 IDPs living in camps, plus a few others living close to special voting centres, were enfranchised. Meanwhile, there were over one million registered voters in the troubled areas of these three states. When IDPs in other states are added, the number of disenfranchised IDPs, that is those not living in camps, becomes very large (about 2152000 going by IDMC [2016] estimates). This is in clear violation of the Guiding Principles 1(1) and 22(1) (d). Meanwhile, Adamawa State had 34 voting centres, Borno State had sixteen, and Yobe State had two (Ukaibe 2015). These few centres could not have adequately taken care of all the registered voters who were displaced in the three states. Apart from the discrimination against other geopolitical zones of the country, some states in the north-east with insurgency-induced displaced persons were also discriminated against. Table 4 below shows the six states of the north-east with the number of internally displaced persons as at February 2015.

Table 4

Total IDPs Population (North-East) by Current Location (as at February 2015)

\begin{tabular}{|l|c|c|}
\hline Current Location & IDPs Individuals & IDPs Households \\
\hline Adamawa & 220159 & 25807 \\
\hline Bauchi & 60555 & 9881 \\
\hline Borno & 672714 & 76842 \\
\hline
\end{tabular}




\begin{tabular}{|l|r|r|}
\hline Gombe & 24655 & 3335 \\
\hline Taraba & 74125 & 11599 \\
\hline Yobe & 135810 & 21893 \\
\hline Total & $\mathbf{1 1 8 8 0 1 8}$ & $\mathbf{1 4 9 3 5 7}$ \\
\hline
\end{tabular}

Source: NEMA $(2015$, p. 3)

Of the six states in the region listed in Table 4 above, Bauchi, Gombe and Taraba with a total IDP population of 159335 were completely neglected in the arrangement. Fourth and finally, Principle 20(2) of the Guiding Principles provides that the authorities concerned shall issue IDPs with all documents necessary for the enjoyment and exercise of their legal rights without imposing unreasonable conditions. Meanwhile, there is a provision in Section 13(2) of the Electoral Act 2010 (as amended) stipulating that a voter who intends to transfer his registration to another constituency must do so not less than 30 days before the date of the election and that the application must be accompanied by the applicant's voter's card. While this provision/condition was relaxed or waived for the IDPs in the north-east, those from the other geopolitical zones were not given the waiver in total disregard of the Guiding Principles. In particular, there is only a remote possibility that IDPs fleeing from threats to their lives would remember to take their voter's card along with them. Therefore, the condition that the application for transfer must be accompanied by the voter's card makes it all the more difficult for IDPs to exercise their franchise.

As regards the Kampala Convention, Article 1(k) of the Convention defines internally displaced persons as persons or group of persons who have been forced or obliged to flee or to leave their homes or places of habitual residence, in particular as a result of or in order to avoid the effects of armed conflict, situations of generalised violence, violations of human rights or natural or human-made disasters, and who have not crossed an internationally recognised state border. The Convention is the world's first continental instrument that legally binds governments to protect the rights and wellbeing of people forced to flee their homes by conflict, violence, disasters and human rights abuses (IDMC 2014). The Convention was adopted on 23 October 2009 and came into force on 6 December 2012. Nigeria signed the Kampala Convention on 23 October 2009, and ratified same on 17 April 2012. However, the Nigerian Government has not domesticated the Kampala Convention in accordance with Section 12(1) of the 1999 Constitution. Nevertheless, since Nigeria has signed and ratified the Convention, Nigeria is bound by it (Ibeanu 2015). As with the UN Guiding Principles, the Kampala Convention also provides for the electoral rights of IDPs (see Table 5 below). 


\section{Table 5}

\section{Provisions of the Kampala Convention on the Voting Rights of IDPs}

\begin{tabular}{|l|l|}
\hline Article & Provisions \\
\hline 9(1)(a) & $\begin{array}{l}\text { States parties shall protect the rights of internally displaced persons regardless } \\
\text { of the cause of displacement by refraining from, and preventing...discrimina- } \\
\text { tion against such persons in the enjoyment of any rights or freedoms on the } \\
\text { grounds that they are internally displaced persons. }\end{array}$ \\
\hline $\mathbf{9 ( 2 ) ( 1 )}$ & $\begin{array}{l}\text { States parties...shall take necessary measures to ensure that internally displaced } \\
\text { persons who are citizens in their country of nationality can enjoy their civic } \\
\text { and political rights, particularly public participation, the right to vote and to be } \\
\text { elected to public office. }\end{array}$ \\
\hline $\mathbf{1 1 ( 2 )}$ & $\begin{array}{l}\text { States parties shall enable internally displaced persons to make a free and in- } \\
\text { formed choice on whether to return, integrate locally or relocate by consulting } \\
\text { them on these and other options and ensuring their participation in finding sus- } \\
\text { tainable solutions. }\end{array}$ \\
\hline 13(2) & $\begin{array}{l}\text { States parties shall ensure that internally displaced persons shall be issued with } \\
\text { relevant documents necessary for the enjoyment and exercise of their rights, } \\
\text { such as passports, personal identification documents, civil certificates, birth cer- } \\
\text { tifications and marriage certificates. }\end{array}$ \\
\hline 13(3) & $\begin{array}{l}\text { States parties shall facilitate the issuance of new documents or the replacement } \\
\text { of documents lost or destroyed in the course of displacement, without imposing } \\
\text { unreasonable conditions, such as requiring return to one's area of habitual resi- } \\
\text { dence in order to obtain these or other required documents. The failure to issue } \\
\text { internally displaced persons with such documents shall not in any way impair } \\
\text { the exercise or enjoyment of their human rights. }\end{array}$ \\
\hline
\end{tabular}

Source: UNHCR (2009). Kampala Convention

The provisions of the Kampala Convention listed in Table 5 above are drawn directly from the UN Guiding Principles. In other words, the two documents complement each other in their provisions for the electoral rights of IDPs. From the analysis thus far, it is clear that INEC's handling of the voting rights of IDPs in the 2015 general elections clearly contravened the provisions of the UN Guiding Principles and the Kampala Convention.

\section{IDP Voting Rights and the Constitution of the Federal Republic of Nigeria 1999 (As Amended)}

The Nigerian 1999 Constitution (as amended) is one of the two domestic legal frameworks that shaped the conduct and administration of the 2015 general elections in Nigeria. The Constitution did not make any specific provision for IDP voting, but in several sections of the Constitution (Sections 77, 117, 132, and 178), provisions were made for all eligible Nigerians who had attained the age of 18 
years to register and vote during elections. These provisions do not discriminate against any eligible Nigerian, as the Constitution itself provided in Section 42(1) that a citizen of Nigeria of a particular community, ethnic group, place of origin, sex, religion or political opinion shall not, by reason only that he is such a person, be subjected to restrictions to which other citizens of Nigeria are not made subject, or be accorded any privilege or advantage that is not accorded to other Nigerians. In other words, internally displaced persons and other disadvantaged groups shall not be discriminated against, or accorded undue advantage in the exercise of their voting rights simply because of their prevailing status as displaced persons. They shall enjoy what other Nigerians enjoy, and be denied what other Nigerians are denied. Table 6 below shows the provisions of the 1999 Constitution which guarantee the right to vote to all eligible Nigerians, including IDPs.

\section{Table 6}

\section{Provisions of the 1999 Constitution (as amended) on the Voting Rights of Eligible Nigerians}

\begin{tabular}{|l|l|}
\hline Section & Provisions \\
\hline $\mathbf{7 7 ( 2 ) ; \mathbf { 1 1 7 } ( 2 )}$ & $\begin{array}{l}\text { Every citizen of Nigeria, who has attained the age of eighteen years resid- } \\
\text { ing in Nigeria at the time of registration of voters for purposes of election } \\
\text { to a legislative house, shall be entitled to be registered as a voter for that } \\
\text { election. }\end{array}$ \\
\hline $\mathbf{1 3 2 ( 5 )}$ & $\begin{array}{l}\text { Every person who is registered to vote at an election of a member of a legis- } \\
\text { lative house shall be entitled to vote at an election to the office of President. }\end{array}$ \\
\hline $\mathbf{1 7 8 ( 5 )}$ & $\begin{array}{l}\text { Every person who is registered to vote at an election of a member of a legis- } \\
\text { lative house shall be entitled to vote at an election to the office of Governor } \\
\text { of a State. }\end{array}$ \\
\hline
\end{tabular}

Source: Federal Republic of Nigeria (1999)

Table 6 above indicates that every eligible Nigerian who has attained the age of 18 years shall be entitled to register and vote during elections. These provisions also apply to IDPs irrespective of their status as displaced persons. The 1999 Constitution does not discriminate against IDPs. But in the administration of the 2015 general elections, some IDPs from some sections of the country were discriminated against even when they were duly registered to vote. As arrangements were being made for IDPs in the three north-east states of Adamawa, Borno, and Yobe, INEC announced that for the sake of the 2015 general elections, IDP voting would be restricted to those states. This deprived IDPs from other states from exercising their franchise, even when the 1999 Constitution had guaranteed such right to vote. Though it is an incontrovertible fact that these three states were the most affected by insurgency, and as a result had the highest 
number of displaced persons (as shown in Table 4 above), other states such as Bauchi and Taraba also had large numbers of displaced persons. Also, if data on the number of southerners displaced from the north as a result of insurgency and electoral violence had been available, it would have made INEC's reasoning for concentrating only in the north-east untenable. In addition, the argument that the choice of only these three states was because IDPs were living in clusters in camps and camp-like settlements, was unacceptable. NEMA (2015) and Ibeanu (2015) observed that before the 2015 general elections, there were no IDP camps in Yobe State; yet, there was IDP voting in this state.

From the foregoing, it is evident that to a large extent INEC's handling of the voting rights of IDPs in Nigeria's 2015 general elections did not comply with the provisions of the 1999 Constitution (as amended). IDPs in other states (especially those in the southern part of the country) could not vote, even when they had registered to vote prior to their displacement. In addition, while IDPs in the three states of Adamawa, Borno and Yobe were given the opportunity to re-register in order to vote, such opportunities were not extended to IDPs in other states.

\section{IDPs Voting Rights and the Electoral Act 2010 (As Amended)}

Just as with the 1999 Constitution, the Electoral Act 2010 had no provisions specifically protecting the right to vote of displaced persons or making specific provisions to ensure such voting. The National Assembly, whose duty it was to enact these laws, made attempts to incorporate IDP voting into the amendments being proposed before the elections. Thus, on 19 November 2014, a bill was introduced in the Senate seeking to amend Section 42 of the Electoral Act 2010 in order to establish polling units for IDPs in their respective camps. The bill, cited as the Electoral Act 2010 (Amendment) Bill 2014, was meant to establish polling units for eligible voters who had been forced to flee from their homes by the terrorist group Boko Haram. The bill sought to amend Section 42 of the Electoral (Amendment) Act 2010 by inserting subsection 42(2) to ensure that IDPs were able to exercise their right to vote in the 2015 elections. The amendment to Section 42 of the Electoral Act 2010 stated that 'The Commission shall establish Polling Units for Internally Displaced Persons (IDPs) in their respective camps nationwide' (PLAC 2014). However, the bill was later stalled at its second reading in December 2014, as the Senate was of the view that a resolution employing INEC to use all administrative mechanisms within the Electoral Act 2010 to ensure that IDPs of adult age exercised their franchise in time of general elections would be more effective (PLAC 2015). Hence, on 16 December 2014, Senate directed its Committee on INEC to liaise with INEC over the possibility of enfranchising IDPs. Subsequently, INEC set up a task force on IDP voting. Table 7 below shows 
sections of the Electoral Act 2010 (as amended) that provide for the voting rights of eligible Nigerians, including eligible IDPs.

\section{Table 7}

\section{Provisions of the Electoral Act 2010 (As Amended) on the Voting Rights of Eligible Nigerians}

\begin{tabular}{|l|l|}
\hline Section & Provisions \\
\hline $\begin{array}{l}\text { 12(1) } \\
\text { (a) } \\
\text { (c) }\end{array}$ & $\begin{array}{l}\text { A person shall be qualified to be registered as a voter if such a person: } \\
\text { is a citizen of Nigeria; } \\
\text { has attained the age of } 18 \text { years; } \\
\text { is ordinarily resident, work in, originate from the Local Government Area } \\
\text { Council or Ward covered by the registration centre; } \\
\text { presents himself to the registration officers of the Commission for registration } \\
\text { as a voter; and } \\
\text { is not subject to any legal incapacity to vote under any law, rule or regulation } \\
\text { in force in Nigeria. }\end{array}$ \\
(e) & $\begin{array}{l}\text { A person who before the election is resident in a constituency other than the } \\
\text { one in which he was registered may apply to the Resident Electoral Commis- } \\
\text { sioner of the State where he is currently resident for his name to be entered on } \\
\text { the transferred voters' list for the constituency. }\end{array}$ \\
\hline $\mathbf{1 3 ( 2 )}$ & $\begin{array}{l}\text { An application under Subsection (1) of this Section shall be accompanied by the } \\
\text { applicant's voter's card and shall be made not less than } 30 \text { days before the date } \\
\text { of an election in the constituency where the applicant is resident. }\end{array}$ \\
\hline $\mathbf{5 8}$ & $\begin{array}{l}\text { No person shall be permitted to vote at any polling unit other than the one to } \\
\text { which he is allotted. }\end{array}$ \\
\hline
\end{tabular}

Source: Federal Government of Nigeria (2010).

Before the other conditions as stipulated in paragraphs (c) to (e) of Section 12(1), the Electoral Act 2010 (as amended) firstly granted the right to register and vote to all Nigerians (paragraph [a]) who have attained the age of 18 years (paragraph [b]). It did not preclude IDPs from exercising this right. As much as this right was granted to some IDPs in the north-east, the same right was denied to the majority of other IDPs, especially those from the southern part of the country. Section 58 of the Electoral Act 2010 stipulates that no person shall be permitted to vote at any polling unit other than the one to which he/she is allotted. This seemed to have provided an alibi for INEC to deny the right to vote in the 2015 general elections to those who escaped insurgency and electoral violence in the north and returned to their home states in the south. But this argument cannot be sustained since Senate had already mandated INEC to use all administrative mechanisms within the Electoral Act 2010 to ensure that IDPs were not disenfranchised. This was based on the Senate's directive that IDP voting was made possible in the north-east. 
Since it was possible in the north-east, why was it not possible in other parts of the country? This disenfranchisement of other IDPs gave credence to the belief in some quarters that the entire IDP voting arrangement was tailored towards giving an undue advantage to the presidential candidate of the opposition All Progressives Congress, who had a large following in the north, especially as the INEC chairman also hails from the north. The argument is thus that the Electoral Act 2010 did not only fail to make adequate protection for IDP voting, but also that the inability to apply relevant provisions of the Electoral Act 2010 resulted in discrimination against the voting rights of IDPs, especially those from the southern part of the country.

Section 13(1) and (2) of the Electoral Act 2010 provides the conditions which a prospective voter, intending to vote in a constituency other than where she or he has registered, has to meet before her or his registration is transferred. But as noted earlier, the process is cumbersome, and for a person fleeing danger, thinking about voting would be the least of his/her problems. Moreover, INEC itself announced before the polls that it was at that time encumbered with the distribution of permanent voters' cards, and as such, there would be no time to entertain applications for transfer of registration, thereby sealing the fate of those who might have wanted to do so. If INEC had wanted to apply Sections 13(1) \& (2) and 58 of the Electoral Act 2010 strictly, IDPs in the north-east would not have voted. In the first place, they voted in constituencies other than where they registered (in violation of Section 58 of the Electoral Act 2010). Secondly, these IDPs could not have made formal applications to INEC for their registrations to be transferred to the camps where they voted, given the circumstances under which they were displaced. Enfranchising these IDPs also violated Section 13(1) and (2) of the Electoral Act 2010. From the foregoing analysis it is also evident that INEC's handling of the voting rights of IDPs in the 2015 general election to a large extent contravened the provisions of the Electoral Act 2010 (as amended). Nevertheless, it is also important to note that INEC had some challenges implementing all the necessary mechanisms needed to ensure that IDPs were enfranchised.

First, 2015 was the first election in which Nigeria allowed for IDP voting so there was no existing structure for such an exercise.

Second, the preparation for the IDPs voting did not commence on time. It was after the INEC management team visited Adamawa State in preparation for the governorship by-election in the state that the Commission became aware that many Nigerians would be disenfranchised if there was no urgent action to incorporate IDPs into the voting arrangement.

Third, pooling resources to cater for all IDPs scattered all over Nigeria was complex, since INEC's budget had been approved long before the issue of IDP voting was considered. 
Having examined the four legal frameworks that shaped the conduct and administration of IDPs voting in the 2015 general elections in Nigeria, and given the available empirical evidence, we establish that INEC failed to conform to the relevant provisions of these legal frameworks regarding IDP voting.

\section{INADEQUATE PROVISION FOR IDP VOTING IN THE 2015 GENERAL ELECTIONS}

Thus far, the study has demonstrated that to a large extent INEC did not comply with the relevant provisions of the legal instruments guiding IDP voting in Nigeria's 2015 general elections. This resulted in the disenfranchisement of several IDPs who had registered to vote during the elections. While some of the IDPs voted, particularly in the three IDP states of the north-east, several were disenfranchised, especially in the southern part of the country. These included southerners who were escaping danger and returning to their states of origin. The official reason given by INEC for inadequate provisions for IDP voting hinged on issues relating to the lack of institutional capacity, costs and logistics. As already noted above, there were challenges regarding the implementation of all necessary mechanisms for IDP voting. This was corroborated by the INEC staff that were interviewed, who posited that there was no existing structure for such an exercise since 2015 was the first time IDP voting would take place in Nigeria. Also, enfranchising all IDPs in the country seemed problematic because there was paucity of data regarding their number and location. Substantial resources and time would be required for this and INEC was constrained on both, since IDP voting was not originally budgeted for.

However, there was another school of thought, especially amongst southerners. They believed that the main reason why INEC's arrangement for IDP voting did not include southerners in particular, was to disenfranchise the many southerners who returned from the north before the elections. The People's Democratic Party (PDP) candidate, then incumbent President Goodluck Jonathan, had a large support base in the south (being a southerner himself), and the assumption was that the majority of southerners living in the north (who had to return to the south to escape post-election violence likely to occur in the north) would vote for him. This school of thought believed that INEC's announcement that those preventively fleeing from anticipated electoral violence would not be allowed to vote in their new location, was meant to give undue advantage to the presidential candidate of the then opposition All Progressives Congress (APC). This was because the APC had a large following in the north especially given the fact that the INEC chairman also hails from the north. Though there is no data on how many people in the south were affected, it is generally believed 
that the number was high enough to change the electoral outcome. Southerners, especially the Igbo of the south-east, had a large representation in the north, and they returned in droves prior to the elections.

The argument above seems superior to the one offered by INEC. The reason for this position is based on the fact that since INEC was able to get IDPs both in camps and those close to the camps in the north-east to vote in areas where they had not registered, there was no basis for asking those in the south to return to the places where they registered in order to vote. Secondly, if the extra costs were the issue, Nigeria's National Assembly had supplementary budgets from government ministries, departments and agencies; if personnel/capacity was the case, INEC has always depended on ad-hoc staff to execute elections in Nigeria. The Commission could have recruited more ad-hoc staff both for the planning and actual conduct of the IDP voting.

\section{ELECTRONIC VOTING}

Electronic voting (or what is commonly known as e-voting) refers to a system of voting through electronic means, or which is technology-based. E-voting 'is often seen as a tool for making the electoral process more efficient and for increasing trust in its management' (International IDEA 2011, p. 1). Electronic voting is a system in which the casting, counting and recording of votes in elections and referendums involves information and communication technologies. E-voting solutions, when they are well implemented, can increase the security of the ballot and make voting easier. Electronic voting also ensures more accurate results as human error is substantially eliminated. To a large extent, e-voting also protects the electoral process against fraudulent practices by politicians, speeds up the process of collating election results, and in the long term could reduce the cost of conducting elections, by at least eliminating shipment costs. More importantly, for countries faced with the problem of internal displacement, electronic voting solves the problem of disenfranchisement that could arise from displacement because it allows eligible voters to vote regardless of their location at the time of elections. In other words, it encourages the electoral participation of eligible voters who might have relocated from the areas where they originally registered to vote. Thus, in countries where e-voting is practised, the geographical location of voters at the time of the elections is immaterial, as they can vote anywhere - that is, anywhere in the country concerned. However, some advanced countries have also introduced internet or online voting. This enables even those citizens who are resident in foreign countries to vote during their national elections. The United States of America introduced this system in 2000 (Kelleher 2013). Norway piloted internet voting in its 2011 local elections after several years of system development 
and pre-testing (Gjosteen 2013). Kenya also used electronic voting in their 2017 presidential elections. Kenya's electoral body introduced a system known as Kenya Integrated Elections Management System (KIEMS) whose aim was to make sure that the election was secure and transparent. KIEMS was to hold data on voter and candidate registration, voter verification and result transmission. The KIEMS tablets were configured to reject entries that exceeded the voter turnout in respective polling centres, making it impossible to cast more votes than the station was allowed. The system was capable of transmitting the text results and the results declaration form that is scanned (Kamau 2017).

However, electronic voting is not without its challenges. In countries that are not technologically advanced, and coupled with (or compounded by) concerns of forced migration, e-voting attempts could result in disaster. In such countries, the system could create several problems capable of discrediting the exercise, and thereby undermining confidence in the entire electoral process. In countries such as Nigeria where the illiteracy level is high, many eligible voters might be disenfranchised owing to their inability to understand the technology and how it is used. As a corollary to the above, e-voting systems therefore require vigorous, additional voter education campaigns, which cost more time and money. There is also the risk that the system could be manipulated by people with privileged access to the system, or by hackers from outside. In other words, politicians who are desperate to win elections could compromise those whose duty it is to manage the system. Therefore, large-scale electoral fraud and manipulation by a small group of people is highly likely. Finally, the additional cost of purchasing and maintaining electronic voting systems increases the financial burden of elections.

\section{CONCLUSION AND RECOMMENDATIONS}

From the data at our disposal, the research findings reveal that INEC's handling of the voting rights of IDPs in the 2015 general elections in Nigeria was inconsistent with the extant global legal frameworks that guide IDP voting. Such legal frameworks include the United Nations Guiding Principles on IDPs; the Kampala Convention; the 1999 Constitution (as amended); and the Electoral Act 2010 (as amended). Therefore, to a large extent INEC did not comply with the existing global legal frameworks on IDP voting in the conduct of the 2015 general elections in Nigeria. Based on the above findings, the study makes the following recommendations:

INEC should, as a matter of urgency, introduce the system of electronic voting in Nigeria. This is one of the recommendations suggested by the INEC staff who were interviewed. Though electronic voting is not entirely free from corrupt manipulation by officials and politicians, it will go a long way towards minimising 
disenfranchisement resulting from the location of the electorates during elections. Therefore, this system will enable all eligible Nigerians to vote in whichever part of the country they are resident at the time of the election. It will settle issue of disenfranchisement based on residency requirements. It is good news that the Nigerian Senate has already given legal backing to electronic voting by passing the Electoral Act 2010 (Amendment) Bill 2017 which incorporates electronic voting.

The National Assembly should amend the necessary sections of the electoral laws to provide for IDP voting. The fact that there were no laws that expressly supported IDP voting in the 2015 general elections limited INEC's capacity to deliver. Whenever an election is about to take place in Nigeria, there is always a review of the extant electoral law by the National Assembly. The idea is to improve on the laws following the experiences of the previous election, especially the hitches encountered therefrom. Presently, a review of the 2010 Electoral Act (as amended) - which was used for the 2015 elections - is in progress. INEC should leverage on this and liaise with the National Assembly to ensure this bottleneck is removed by getting IDP voting enshrined in the electoral act. In addition to this, some of the international conventions and statutes on political participation of IDPs, which Nigeria has ratified, should be domesticated and incorporated in the national laws.

Finally, the federal government of Nigeria and INEC should ensure that in subsequent elections, IDPs in other parts of the country are also allowed to vote. Certainly, this would require more rigorous planning and costs in terms of funds and personnel. Government should, therefore, empower INEC by providing more funding to enable the commission to recruit and train more ad-hoc staff during the elections. Arrangements for this should start long before the elections so that there would be enough time for planning, unlike the recent incidents involving with IDPs during the 2015 general elections. Having been enabled both in terms of legal provisions and funding, the onus would then lie with INEC to ensure that all eligible Nigerians vote in subsequent elections irrespective of where they are resident at the time of the elections.

\section{- REFERENCES -}

Africa News 2015, 'Registered IDPs to Vote in Nigeria's General Elections: Electoral Chief', retrieved from www.xinhuanet.com/english/africa/201501/20/c_133933589.htm

African Heritage 2012, 'History of Constitutional Development in Nigeria: An Overview', retrieved from www.shinaalimi.blogspot.com.ng/2012/10/ history-of-constitutional-development.html? $\mathrm{m}=1$ 
Aghalino, SO 2006, 'Dynamics of Constitutional Development in Nigeria, 1914-1999', Indian Journal of Politics vol. XL, nos. 2 and 3, pp. 49-62.

Akpotor, AS 2015, 'Legal Framework for Elections in Nigeria: A Study of the 2015 General Elections', Paper presented at a two-day National Conference on the 2015 General Elections in Nigeria: The Real Issues, The Electoral Institute, Abuja, July 27-28.

Azinge, E 1994, 'The Right to Vote in Nigeria: A Critical Commentary on the Open Ballot System', Journal of African Law vol. 38, no. 2, pp. 173-180.

Brookings Institution 2008, 'Protecting Internally Displaced Persons', A Manual for Law and Policy, retrieved from www.brookings.edu/media/research/files/ papers/2008/10/16-internal-displacement/10_internal_displacement_manual. pdf

Carter, C 2011, 'The Right to Vote for Non-Resident Citizens: Considered Through the Example of East Timor', Texas International Law Journal vol. 46, pp. 655-674.

CLEEN Foundation 2014, 'Election Security Threat Assessment: Towards 2015 Elections' Newsletter, Eighth Edition, December.

Foster, F 2015, 'Nigerian IDPs at Risk of Going Unheard in Upcoming Elections', retrieved from www.internal-displacement.org/blog/2015/nigerian-idps-atrisk-of-going-unheard-in-upcoming-elections

Gjosteen, K 2013, 'The Norwegian Internet Voting Protocol', retrieved from www. eprint.iacr.or/2013/473.pdf

Grace, J 2003, 'The Election Rights of Conflict Forced Migrants: A Review of Relevant Legal Norms and Instruments', Discussion Paper Number 1, Participatory Elections Project, International Organization for Migration, Geneva.

Grace, J \& Fischer, J 2008, 'Seeking Electoral Equality for IDP Voters', Forced Migration Review, Special Edition: Ten Years of the Guiding Principles, Oxford.

Grace, J \& Mooney, E 2007, 'Democracy and the Displaced: Political Participation Rights, in Particular the Rights to Vote and to be Elected', retrieved from http://www.geneseo.edu/ iompress/grace_mooney_IDP_participation.pdf Hassan, I 2015, 'An Appraisal of the Legal Framework for the Conduct of the 2015 General Elections: Matters Arising', Paper presented at a two-day National Conference on 'The 2015 General Elections in Nigeria: The Real Issues', organized by The Electoral Institute, Abuja, July 27-28.

Human Rights Watch 2011, 'Nigeria: Post-Election Violence Killed 800', retrieved from www.hrw.org/news/2011/05/16/nigeria-post-election-violencekilled-800

Ibeanu, O 2015, 'Between Refuge and Rights: Internally Displaced Persons and Inclusive Electoral Process in Nigeria', Public lecture delivered at The Electoral Institute, Abuja, December 15, retrieved from www.inecnigeria.org/wpcontent/uploads/2015/12/Final-TEI-Lecture-Dec-10-by-Prof-Ibeanu.pdf 
Independent National Electoral Commission 2015a, 'INEC Raises Task Force on IDPs', retrieved from www.inecnigeria.org/?inecnews=inec-raises-taskforce-on-idps

Independent National Electoral Commission 2015b, 2015 General Elections Report, INEC, Abuja.

Internal Displacement Monitoring Center 2013, ‘Global Estimates 2012: People Displaced by Disasters', retrieved from www.internal-displacement.org/ publications/2013/global-estimates-2012-people-displaced-by-disasters

Internal Displacement Monitoring Center 2014, 'The Kampala Convention: Two Years On: Time to Turn Theory into Practice', retrieved from www.internaldisplacement.org/sub-saharan-africa/kampala-convention

Internal Displacement Monitoring Center 2015a, 'Global Overview 2015: People Internally Displaced by Conflict and Violence', retrieved from www. internal-displacement.org/publications/2015/global-overview--2015-peopleinternally-displaced-by-conflict-and-violence.

Internal Displacement Monitoring Center 2015b, 'Global Estimates 2015: People Displaced by Disasters', retrieved from www.internal-displacement.org/ publications/2015/global-estimates-2015-people-displaced-by-disasters

Internal Displacement Monitoring Center 2016, 'Nigeria IDP Figures Analysis', retrieved from www.internal-displacement.org/sub-saharan-africa/nigeria/ figures-analysis

International Federation of Red Cross and Red Crescent Societies 2013, 'Nigeria: Floods', Information Bulletin 1, retrieved from www.ifrc.org

International Institute for Democracy and Electoral Assistance (International IDEA) 2011, 'Introducing Electronic Voting: Essential Considerations', Policy Paper, International IDEA, Stockholm.

Kamau, J 2017, 'Kenya's Long Journey to Electronic Voting System', Daily Nation, retrieved from http://www.nation.co.ke/news/politics/Kenya-s-long-journeyto-electronic-voting-system/1064-4051950-mwqfgq/index.html

Kelleher, WJ 2013, 'Internet Voting in the USA: History and Prospects', Paper prepared for the annual meeting of the Western Political Science Association, Los Angeles, California, March 28-30, 2013, retrieved from www.eac.gov/assets/1/28/ William-Kelleher-Internet-Voting-WPSA-Paper-July-9th.pdf

Mooney, E \& Jarrah, B 2004, 'The Voting Rights of Internally Displaced Persons: The OSCE Region' Occasional Paper, Johns Hopkins SAIS Project on Internal Displacement, Washington DC, The Brookings Institution.

Moveh, DO 2015, 'INEC and the Administration of Elections in Nigeria's Fourth Republic: The 2015 General Elections in Perspective', Paper presented at a twoday National Conference on The 2015 General Elections in Nigeria: The Real Issues, organised by The Electoral Institute, Abuja, July 27-28. 
National Emergency Management Agency 2015, Displacement Tracking Matrix 1: Round II Report, NEMA, Abuja.

Nigeria 1999, Constitution of the Federal Republic of Nigeria, 1999, Federal Ministry of Justice, Abuja.

Nigeria 2010, Electoral Act, 2010 Official Gazette, The Federal Government Printer, Abuja.

Nweje, C 2015, 'Fleeing Residents, IDPs and Need for Electronic Voting', retrieved from www.dailyindependentnig.com/2015/01/fleeing-residents-idps-needelectronic-voting.

Okereka, OP 2015, 'Evolution of Constitutional Government in Nigeria: Its Implementation and National Cohesion', Global Journal of Political Science and Administration, vol. 3, no. 5, pp. 1-8.

Policy and Legal Advocacy Centre 2015, 'Hanging Electoral Fate of Internally Displaced Persons', retrieved from www.placng.org/legist/hanging-electoralfate-of-internally-displaced-persons/more-178

Prather, L \& Herron, E 2007, 'Enfranchising Displaced Voters: Lessons from BosniaHerzegovina', Election Law Journal, vol. 6, no. 4, pp. 354-371.

Rushing, E \& Read, J 2014, 'Nigeria: Multiple Displacement Crises Overshadowed by Boko Haram', retrieved from www.internal-displacement.org/sub-saharanafrica/nigeria/2014/nigeria-multiple-displacement-crises-overshadowedby-boko-haram.

Ukaibe, C 2015, 'Cautious Optimism As Stakeholders Brainstorm Over IDPs Voting', retrieved from www.leadership.ng/news/406152/cautious-optimismstakeholders-brainstorm-idps-voting.

United Nations High Commission for Refugees 1998, Guiding Principles on Internal Displacement, United Nations, New York, retrieved from www.unhcr.org/ protection/idps/43celcff2/guiding-principles-internal-displacement.html

United Nations High Commission for Refugees 2009, African Union Convention for the Protection and Assistance of Internally Displaced Persons in Africa (Kampala Convention), adopted by the Special Summit of the African Union held in Kampala, Uganda, on 23rd October, 2009, retrieved from www.unhcr.org/ about-us/background/4ae9bede9/african-union-convention-protectionassistance-internally-displaced-persons.html

United Nations High Commission for Refugees 2015, 'Internally Displaced People Figures', UNHCR, New York', retrieved from www.unhcr.org/ pages/49c3646c23.html 